\title{
Drifting meio- and macrobenthic invertebrates on tidal flats in Königshafen: a review
}

\author{
W. Armonies \\ Biologische Anstalt Helgoland, Wattenmeerstation Sylt; D-25992 List, \\ Federal Republic of Germany
}

\begin{abstract}
Many benthic species have been recorded to occur in the water column above the tidal flats in Königshafen. They were either passively suspended from the sediment or performed active migrations. Concerning both number of species and organisms, active migrations were more important. The causes for these migrations range from (1) individual escape from a sudden threat such as predator attack, over (2) group evasion of local subpopulations to avoid environmental deterioration, to (3) habitat changing of entire populations. The temporal scales involved range from seconds to seasons, and the spatial scales from $\mathrm{cm}$ to $\mathrm{km}$. Such changes of distribution patterns have been demonstrated in juvenile molluscs and in meiofaunal copepods and plathelminths. Since migrations may interfere with many kinds of population studies in the field, new methods and concepts need to be developed to avoid and overcome pitfalls. As a precaution, the migration potential of benthic species should be taken into account in any field study including population parameters.
\end{abstract}

\section{INTRODUCTION}

Over the past decades, an increasingly long list has been made of the benthic species observed in the water column. The existence of daily or seasonal swimming activity is well established in various taxa such as Amphipoda (cf. Sainte-Marie \& Brunel, 1985; Essink et al., 1989), Cumacea (cf. Maquart-Moulin, 1991), and Isopoda (cf. Warman et al., 1991). Most of these species will readily demonstrate their swimming capabilities when kept in aquaria. However, species unable to swim actively have been observed in the water column as well. They may have been passively eroded from the sediment by strong currents or wave action which is, of course, also a possible cause for the water column entry of species which are able to swim. Other species actively enter the water column to get transported passively with the currents. Examples of the latter group are floating mud snails (Newell, 1962) or byssus-drift of bivalves (cf. Sigurdsson et al., 1976; Beukema \& de Vlas, 1989).

In benthic field research, the possibility of passive removal of specimens from the sediment needs to be taken into account whenever current velocity or wave height exceed the long-term average, particularly during gales. Disregarding the potential of many species to perform active migrations (i.e. swimming, floating, byssus-drift) may introduce severe bias into many benthic studies whenever these migrations are quantitatively important. The distributional pattern of migrating species observed in the field has to be regarded as a snap-shot which may have strongly changed by the next day. On the other hand, periodical sampling may reveal essentially the same distributional patterns, which is usually interpreted as a sign of stability in space and time, but in fact may be the 
result of intermittent changes (cf. Armonies, 1990). In field experiments using cages for predator inclusion, a lack of significant decrease in 'prey' abundance in the enclosures when compared to appropriate controls would certainly be interpreted as 'no predation/ disturbance-effect'. However, this interpretation is only true if the prey is really sedentary and therefore unable to leave or enter the cage. Otherwise, predation/disturbance effects may have been compensated for by immigration of prey specimens. If a predator decimates its prey, immigration of prey into the cages might result in an underestimation of the predator effect.

Because of the effects such distributional changes may exert on field studies, the critical question is whether migrations of benthic species are quantitatively important. In the case of passive erosion, a correlation is expected between the number of eroded specimens on the one hand and current velocity and wave height on the other. The number of transported organisms will be negligible beyond a threshold value of current velocity needed for sediment erosion. As current velocity increases above this threshold the number of eroded specimens will approach the density of the entire population according to the species-specific and age- (size-)specific susceptibility to erosion.

Active migrations do not necessarily depend on current velocity but may be influenced by a variety of physical and biotic factors. The effects of some of those factors have been studied in meio- and macrofaunal populations of the Königshafen wadden area. This paper gives an overview of these studies to shed some light on the mode, quantitative importance, and potential causes of active migrations of benthic species in the Wadden Sea. It turned out that the relative paucity of observations of benthic organisms in the water column did not originate from a paucity of migratory species. Instead, it may be due to the fact that most benthic biologists prefer low tide to high tide, and daylight to the dark of the night, when going out for sampling.

\section{STUDY AREA}

The Königshafen is a wadden area positioned at the northern end of the Island of Sylt in the North Sea. It is a sheltered bay formed by a curving chain of sand dunes which are replaced by a dike in the southern part. An artificial island "Uthörn" separates the bay into a northern and a southern part. Most of the studies on drifting benthos were done in the southern part, comprising $0.75 \mathrm{~km}^{2}$ of mostly sandy tidal flats. Muddy sediment only occurs in a small semi-enclosed bay between the dike and a sandy bar in the southernmost part. Tides are semi-diurnal with an average amplitude of $1.8 \mathrm{~m}$. A more detailed description of the area is given in Reise (1985).

\section{METHODS USED FOR THE STUDY OF DRIFTING BENTHOS IN KÖNIGSHAFEN}

\section{Field methods}

For point estimates of abundance of benthic species in the water column, three methods were used: (1) Scooping of a defined volume of water from the water surface with a bucket was sufficient to demonstrate diurnal differences of meiofaunal abundance in the water column (Fig. 1A; Armonies, 1989c). (2) A column of water was collected by lowering a plastic pipe from the water surface down to the sediment surface (Fig. 1B; 

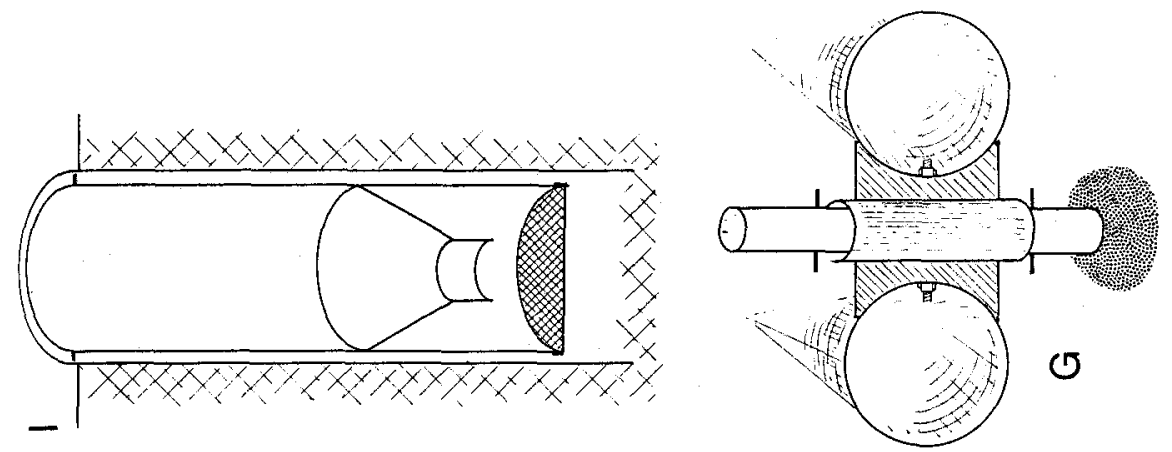

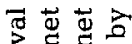

马

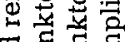

范要焉

品芒范

कั

可宁

记

苍落

岛焉㤩

อั

त苨范

害导记

氙吉起

3 过

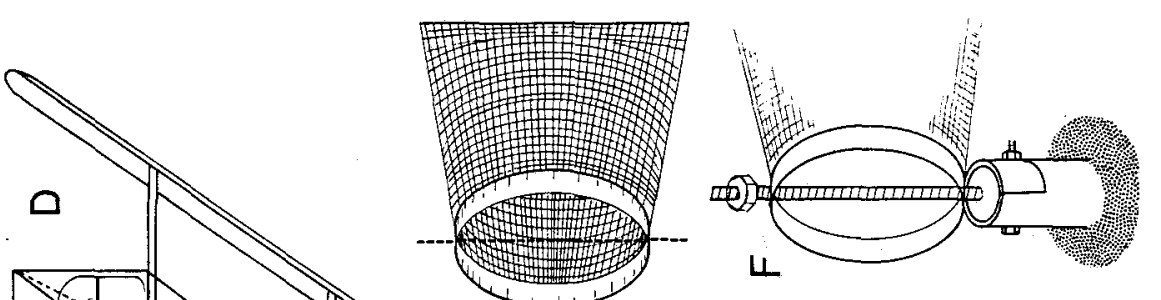

过总氙

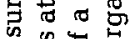

के

焉范

密要

递艺要

$\because 8$ 过

군

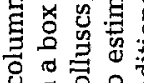

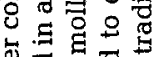

过苋

3 迏

至 总 荡

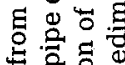

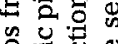

㝴总总

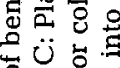

원훈

茟芯声

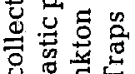

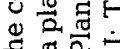

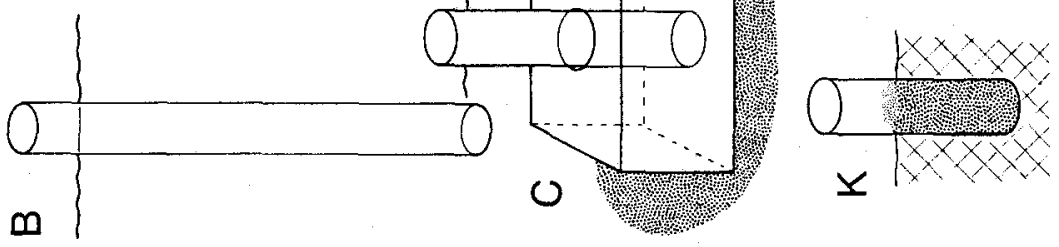

苍趗的

क्ष के

氖要

牙要曹

更 $\pi$

흠열 동 응

诖哥要

-

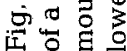


Armonies, 1989c). As an alternative, the same kind of pipe was enclosed in a box, either transparent or black, to estimate the number of meiofaunal organisms entering the water column within 3 minutes in daylight or strongly dimmed light, respectively (Fig. $1 C_{\text {; }}$ Armonies, 1989a). (3) A plankton net mounted on a sledge (Fig. 1D) was used to integrate abundance over spatial scales of 10 to $25 \mathrm{~m}$ (Armonies, 1989c).

The volumes of water filtered or collected with the above gear were appropriate for meiofauna, but too small for most of the macrofaunal drifters. Therefore, plankton nets were anchored at fixed sampling stations, and at a fixed distance above the sediment, to integrate drifting macrobenthos over a longer period, usually a tidal cycle. Because wind exerts a strong influence on the direction of the currents in the shallow waters of Königshafen, all nets were constructed in a manner guaranteeing free rotation around the vertical axis and, thus, self-adjustment of the nets into the currents. Two designs were used, either equipped with double nets or with a single net (Fig. 1E-G). The double net type (Fig. 1G) was used for simultaneous comparisons of the filtering efficiency, for the various taxa, of long $(1 \mathrm{~m})$ versus short $(0.5 \mathrm{~m})$ nets, narrow $(0.5 \mathrm{~mm})$ versus wide $(1 \mathrm{~mm})$ meshes, and to test the effects of inner cones and terminal collecting devices (Armonies, 1992). A short net $(0.5 \mathrm{~m}$ long, diameter of opening $0.2 \mathrm{~m}$ ) with $0.5-\mathrm{mm} \mathrm{mesh}$, formed like a bag, turned out to be most efficient in collecting drifting molluscs (i.e. bad swimmers). Inner cones proved useful for the better swimmers like amphipods and cumaceans, and a terminal collecting device improved maintenance of the more delicate forms like small polychaetes (Armonies, 1992). After these comparisons, the one-net modification was used to collect drifting molluscs (Armonies \& Hartke, 1994; Armonies, 1994). For stratified water column sampling, several nets may be mounted above each other in the two-net design, or several independent one-net gears are placed besides each other. An alternative is to lower a plankton net into the water column for a defined period down to a defined distance above the sediment (Fig. $1 \mathrm{H})$. This was done from a tower placed on the tidal flats. Unlike the other tools for macrobenthic drifters, submerging nets from a tower enables studies on temporal scales shorter than a tidal cycle.

All the methods listed above estimate the abiundance of benthic organisms drifting in the water column, i.e. the number of drifters passing a site. This is not necessarily indicative of the number of drifters landing at a site. Therefore, sediment traps have been used to estimate the number of drifters returning to the sediment (Fig. $1 \mathrm{I}_{i}$ Armonies \& Hartke, 1994; Armonies, 1994). Comparing the number of organisms caught per $\mathrm{m}^{2}$ of trap opening with abundance in the ambient sediment yields estimates of the rates of turnover of the specimens in the sediment.

In order to distinguish between specimens which were passively eroded from the sediment and those which performed active migrations, time series measurements were the standard mode for macrobenthic studies. Abundance of passively eroded specimens in the water column was expected and observed (see below) to increase with increasing current velocity. An estimate of the actual current velocity was derived from a hydrographic model of the Königshafen area (Backhaus \& Hartke, University of Hamburg) fed with measurements of wind speed obtained from the Meteorological Station in List. For active migrators there was a reversed relationship between current velocity and abundance in the water column (see below). Thus, active migrators became rarer in the water column as current velocity increased, while the species which were passively eroded from the sediment became more abundant at the same time. 


\section{Laboratory methods}

In laboratory experiments the distinction between passive displacement and active migrations is no problem, since currents, wave action, and faunal sediment disturbers can be excluded (unless specifically tested). However, laboratory experiments are always in danger of producing mere artifacts, above all because of the restricted spatial dimensions. This may particularly be the case in experiments on migrations because space is one of the studied parameters. Therefore, laboratory experiments have only been made with meiofaunal organisms. As an example, for a 1-mm harpacticoid a Petri dish $8 \mathrm{~cm}$ in diameter (i.e. 80 times the body length) may be equivalent to a sports field for a human being, limited but not very narrow.

Sediment cores collected in the field and containing the specimens to be tested were submerged into aquaria. The size of individual sediment samples varied between 2 and $100 \mathrm{~cm}^{2}$ surface area and the size of the aquaria ranged between 0.5 and $50 \mathrm{dm}^{3}$. The factors tested in these experiments included the specific composition of swimmers, percentage emigration from the sediment cores into the water column during a tidal cycle, the distance meiofauna swims above the sediment (Armonies, 1988a), influence of hydrographic factors (Armonies, 1988b), and influence of physical factors such as light, temperature, oxygen, and salinity (Armonies, 1988c). The experimental setup differed among these experiments and the detailed descriptions will, for conciseness, not be repeated here.

\section{LABORATORY STUDIES ON MEIOFAUNAL MIGRATIONS}

Experimental submergence of natural sediment (containing the specimens to be tested) within glass jars into aquaria revealed that Copepoda, Ostracoda, Plathelminthes, Polychaeta, and juvenile Bivalvia all actively left the glass jars in the absence of currents. This migratory activity was mainly restricted to the dark (simulated night). Although most of the meiofaunal assemblage were Nematoda, not a single specimen was found moving actively out of jars (Armonies, 1988a). While ostracods and bivalves left the jars by climbing up the glass walls, harpacticoids and plathelminths mostly swam free in the water column (Fig. 2; Armonies, 1988a, b). Most of the migratory activity occurred within the first hour of the experiment in the active swimmers (Copepoda and Plathelminthes), while most of the ostracods climbed up the glass walls during the second hour (Armonies, 1988a). Because of this short time scale the migrations are unlikely to be a mere laboratory artifact, e.g. from reduced oxygen concentrations in the absence of currents. Treating meiofauna as a whole, these results show that the taxonomic composition will strongly affect migratory activity.

Flume experiments revealed also differences between taxa. Migratory activity showed no clear dependence on current speed (in the range 0 to $10 \mathrm{~cm} \mathrm{~s}^{-1}$ ) in Ostracoda. The numbers of Nematoda in the water column correlated positively with current velocity, showing a very low abundance in weak flow $\left(1 \mathrm{~cm} \mathrm{~s}^{-1}\right.$ or less) and a steep increase as flow increased above $3 \mathrm{~cm} \mathrm{~s}^{-1}$ and eroded the first particles from the sediment surface (Armonies, 1988b). This correlation was expected in the case of passive resuspension of organisms from the sediment surface. The reverse was true for Copepoda and Plathelminthes. Both were most abundant in the water column under low flow conditions $\left(\leq 1 \mathrm{~cm} \mathrm{~s}^{-1}\right)$ and showed a strong decrease of abundance in the water column as flow 
304

W. Armonies
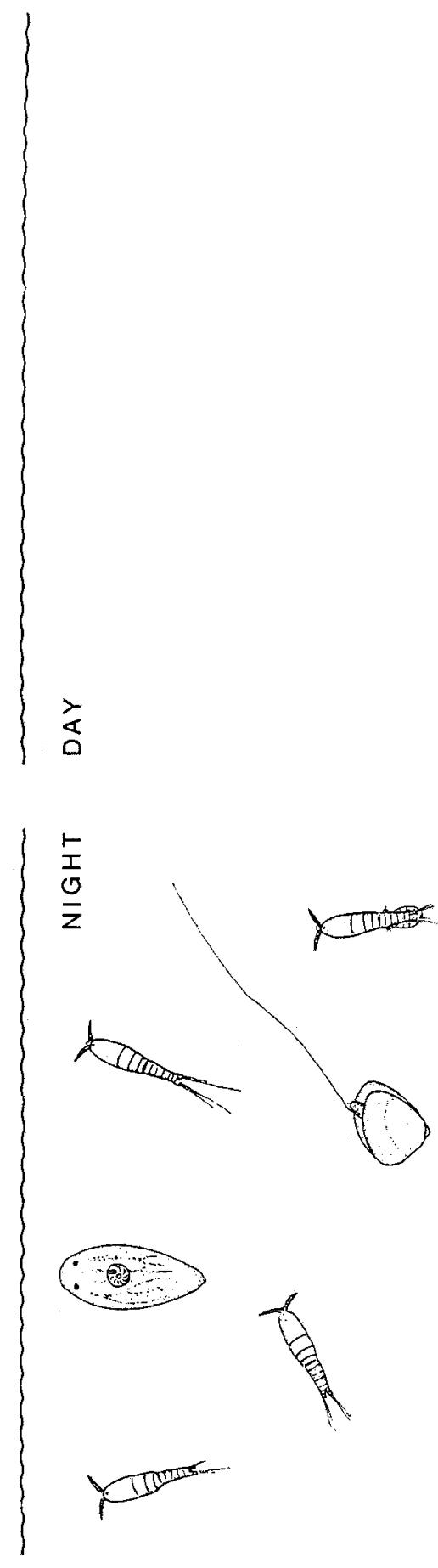
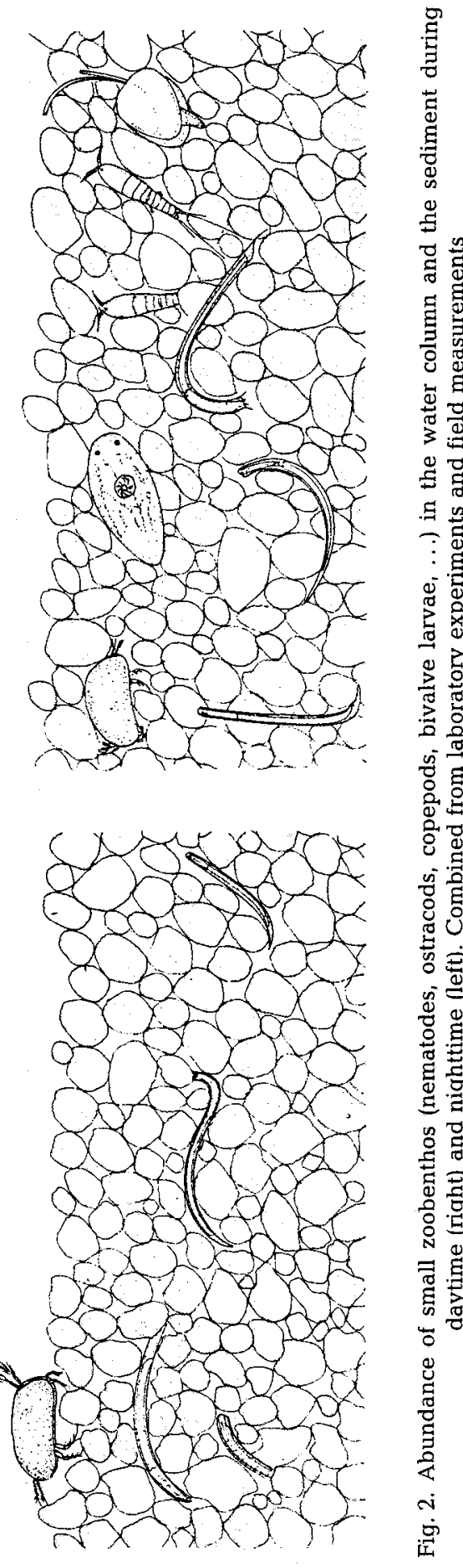

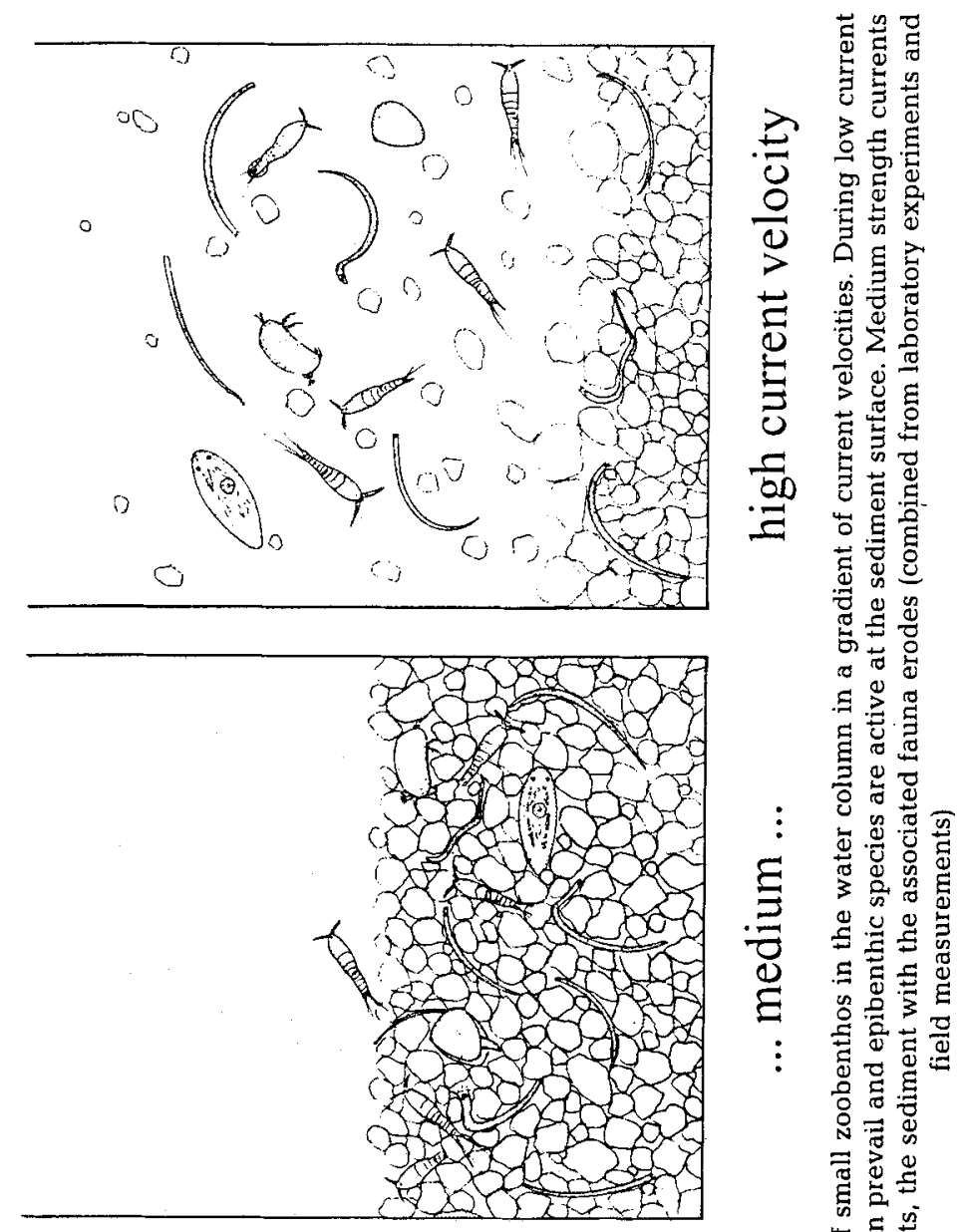

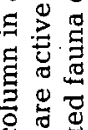

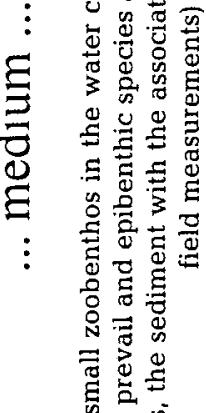
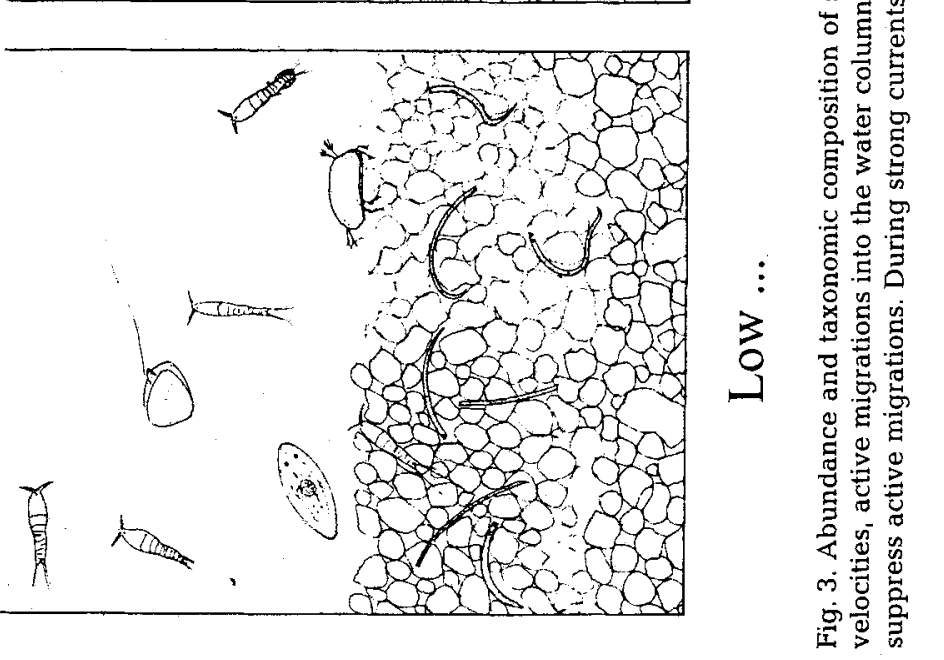
increased above $3 \mathrm{~cm} \mathrm{~s}^{-1}$. A current velocity of $30 \mathrm{~cm} \mathrm{~s}^{-1}$ caused severe erosion of the tested sediment and resuspension of all the meiofauna (Fig. 3). In the absence of flow, hydrostatic pressure did not affect the rates of emergence (Armonies, 1988b). From these results it seems that Copepoda and Plathelminthes use periods of weak flow for their migrations into the water column. As flow increases, active migrations ceased until the currents become strong enough for sediment erosion. Then, all benthic taxa appear in the water column. This non-linear response of the abundance of benthos in the water column to current velocity enables a statistical distinction between active migrations and passive erosion of specimens in the field.

Direct observations of the swimming behaviour of harpacticoids and plathelminths in aquaria revealed species-specific differences in the time spent in the water column and the achieved distance above the sediment. The distributions of both parameters were bimodal, i.e. they showed one peak at a period of a few seconds and a height above the sediment of a few $\mathrm{cm}$, and a second peak at a period of a few minutes and a height of more than $10 \mathrm{~cm}$, respectively. From this it seems there are at least two types of swimming events. The first covers excursions of less than $30 \mathrm{~s}$ to less than $4 \mathrm{~cm}$ height above the sediment. The second includes excursions of $1 \mathrm{~min}$ to $1 \mathrm{~h}$ covering the entire water column offered in these experiments (i.e. $25 \mathrm{~cm}$ ). The horizontal distance covered by both types of swimming events showed a unimodal distribution which is thought to be an artifact of the experimental no-flow conditions (Armonies, 1988b). However, it is currently not clear whether the distinction of these two types of swimming events is an artifact of the restricted number of species tested in these experiments.

Besides current velocity, physical factors like light, temperature, oxygen, and salinity affect the migratory behaviour of meiofauna (Fig. 4; Armonies, 1988c). The effects of light and temperature were similar in all taxa studied. The number of specimens leaving experimentally submerged sediment was highest in the dark and decreased with increasing light intensity (in the range 0 to $1000 \mu \mathrm{mol} \mathrm{m} \mathrm{m}^{-2} \mathrm{~s}^{-1}$ ) and there was a positive correlation between ambient temperature and migratory activity in the range 5 to $25^{\circ} \mathrm{C}$. When oxygen was experimentally changed by storage of the sediment samples in the dark or with light, respectively, the number of copepods leaving these samples during subsequent submersion into aquaria did not differ between treatments. However, significantly more Plathelminthes left the sediment previously stored in the dark (oxygen saturation $<50 \%$ ) than the samples stored in light (oxygen saturation $>100 \%$ ). On the species level, some species of plathelminths left the sediment irrespective of the previous treatment, while others only left the sediment when oxygen concentration had deteriorated (Armonies, 1988c).

When specimens were given the chance to emigrate into water of different salinity, copepods and ostracods showed equally high activity in the range of salinities naturally occurring in the field (i.e. 25 to 35 psu) but a significantly reduced activity outside this range (Armonies, 1988c). In plathelminths there was an inverse relationship between migratory activity and salinity of the overlying water. That is, the majority of plathelminths contained in the tested sediment seem to be attracted by brackish water (also see Armonies, 1986, 1988d). This was also evident in a reciprocal experiment where the interstitial salinity was manipulated and emigration into ambient seawater was measured (Armonies, 1988c). In these experiments, plathelminths tended to leave sediment where salinities were higher than 30 and to stay within a lower salinity sediment. In copepods, 


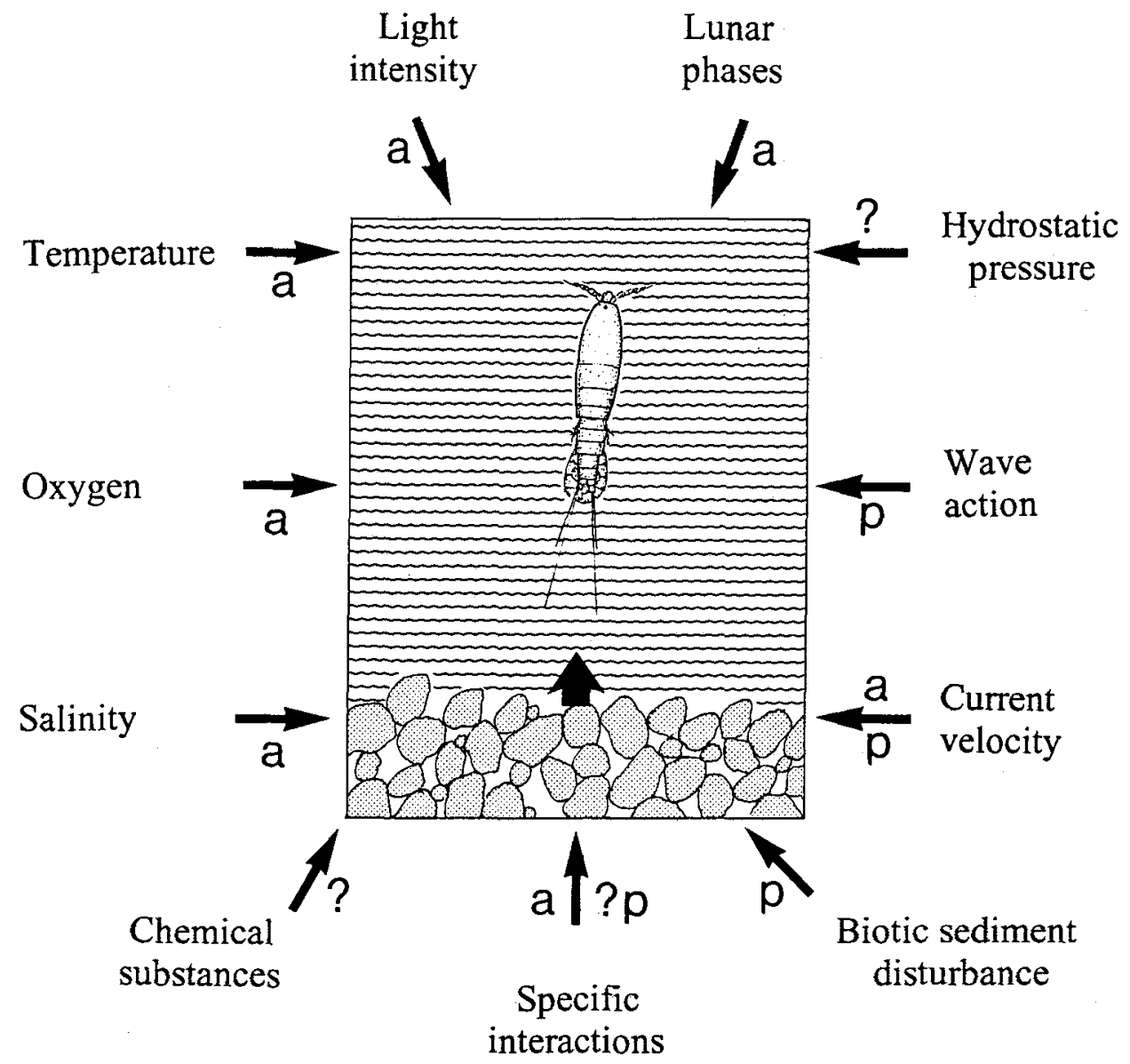

Fig. 4. Factors potentially influencing active (a) or passive (p) water column entry of benthic organisms. An effect of hydrostatic pressure has not yet been demonstrated and chemical substances have not yet been tested. Indirectly, all factors influencing active water column entrance may also have an effect on passive displacement. For example, an upward movement of specimens in the sediment in response to reduced oxygen will, at the same time, increase their susceptibility to biotic sediment disturbance

emergence was strongest at salinity levels between 25 and 45 and decreased towards either side of the range of salinities tested ( 5 to $59 \mathrm{psu}$.)

The species composition of copepods is rather narrow in the tidal flats of Königshafen, with a strong dominance of a few, mostly epibenthic, species (i.e. the harpacticoids Harpacticus flexus and Tachidius discipes and the cyclopoid Cyclopina rotundipes in summer and the harpacticoid Amphiascoides debilis in spring). Therefore, the reactions to physical factors will have been largely determined by these dominants. Plathelminthes, on the other hand, are rich in species both on the tidal flats of Königshafen (some 250 species, Reise, 1988) and among the active swimmers. Therefore, plathelminths were used to look for correlations between swimming activity and preferred food, morphology, 
and their distributional patterns in the sediment (Armonies, 1989b). It turned out that swimming activity in plathelminths was strongest among the species feeding on copepods or diatoms and lowest among those feeding on nematodes or bacteria. During low tide, swimmers mostly resided close to the sediment surface while the subsurface dwellers were all non-swimmers. Finally, body pigmentation and pigmented eye-spots were more common among swimmers than among species behaving like 'sedentary' species. In summary, the assemblage of plathelminths on the tidal flats of Königshafen may be divided into 'truly benthic' species (which have hitherto not been found swimming in the water column), facultative swimmers (which can be experimentally stimulated to swim, e.g. by decreasing oxygen or increasing salinity), and obligatory swimmers which seem to enter the water column whenever possible. However, there are no clearcut boundaries between these groups. They just seem to be stages in a continuous range of life styles from benthic to exclusively planktonic (Armonies, 1989b). Possibly, the situation is similar in copepods.

\section{FIELD STUDIES ON MEIOFAUNAL DRIFT}

Laboratory experiments predicted higher meiofaunal swimming activity during night than day and in slow moving seawater than in strong currents (Figs 2,3). Field measurements confirmed these predictions (Armonies, 1989c). As in the laboratory, copepods were the most abundant taxon among the meiobenthic swimmers in the field (species list for copepods in Armonies, 1989c; for plathelminths in Armonies, 1989b). Two factors contributed to the numerical dominance of copepods among the benthic organisms in the water column: (1) a high frequency of migrations per individual, and (2) a high abundance of copepods within the studied area. As a consequence of meiofaunal swimming, both abundance and biomass of mesozooplankton may be twice as high during night than during daylight in the shallow waters of Königshafen (Armonies, 1989c). However, some meiofaunal swimmers were also observed during daylight. Experimental shading of the sediment increased abundance of swimming copepods significantly within three minutes (Armonies, 1989a). Shading by dense patches of phytoplankton and by seafoam (formed by wave action from the remainders of colonial Phaeocystis globosa) was found to exert a similar effect with a comparable increase in meiofaunal swimmers (Armonies, 1989a).

Meiofauna entering the water column at night will either encounter ebbing or flowing waters causing a seaward or landward transport of the specimens while drifting in the water column. Imagine a transect of three sites from low tide levels to high tide level (Fig. 5). Specimens entering the water column at the most seaward site during a flood tide will be transported in a landward direction where they enter the sediment as the sun rises. This will increase abundance in the sediment at the landward sites and decrease abundance at the seaward site (unless the losses at low tide level are compensated for by immigration from the subtidal area). About one week later, nighttime will coincide with ebbing tides. Specimens now entering the water column will be transported in a seaward direction, decreasing abundance in the sediment of the upper intertidal zone and increasing abundance in the lower intertidal zone. Thus, as a consequence of the preference for migrating in the dark, local changes of abundance in the sediment are expected with a tendency towards an increase during one week and a 


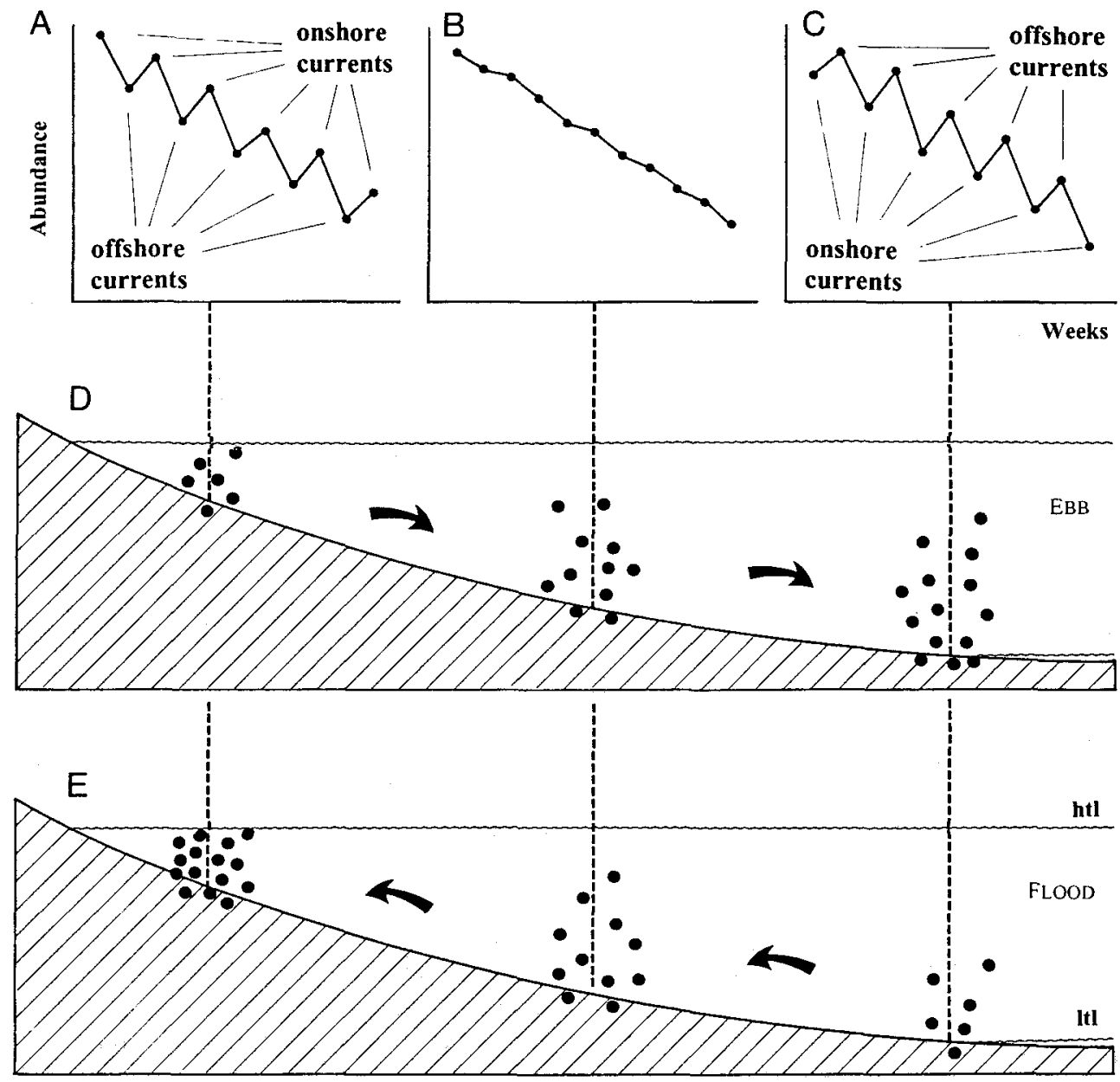

Fig. 5. Transport of nocturnally migrating organisms with the tidal currents. When darkness coincides with flooding waters the entire population is shifted in a landward direction (E). This causes an increase in abundance in the sediment at the landward sites and a decrease at the seaward limit of the population $(A, C)$. In areas in between, abundance may appear unchanged because immigration compensates for emigration of specimens (B). A few days later, darkness will coincide with ebbing waters and the entire process is reversed (D). Thus, abundance in the sediment shows weekly alternations of positive and negative deviations $(A, C)$ from the seasonal trend $(B)$, at least at the landward and seaward limits of distribution. However, unusual changes in direction of the tidal currents may result in aperiodic imports or exports of specimens

decrease during the next week (Fig. 5). This regular pattern is particularly expected in rather widely distributed species and in areas where the directions of the ebbing and flooding waters are diametrically opposed. However, no changes of abundance in the sediment may be observed in the mid-intertidal zone because landward transport may be compensated for by immigration from seaward sites and vice versa. In this case the 
apparent constancy of abundance is a result of an equal balance between emigration and immigration.

Weekly sediment sampling indeed showed the existence of such short-term temporal changes of abundance in the taxa copepoda and plathelminths (Fig. 5; Armonies, 1990). However, regular patterns of ups and downs of abundance in the sediment were only observed in species which occur all over the studied area in similar abundance. In this case, wind-induced changes in the direction of the tidal currents may not show up in the temporal series of local abundance (Fig. 5). Locally restricted populations, on the other hand, may be completely carried out of the studied area or may temporarily show up. In this case, abundance in the sediment will strongly depend on the actual direction of the tidal currents which changes with wind direction and speed. As a result, the changes of abundance in the sediment are not predictable in these species in Königshafen. Therefore, a reliable estimate of average abundance in the sediment will only be obtained by sufficiently repeated or large-scale spatial sampling in taxa containing emergent species (Armonies, 1990).

\section{FIELD STUDIES ON MACROFAUNAL DRIFT}

\section{Species composition and mode of water-column entry}

Juvenile molluscs are the most abundant benthic postlarvae in the tidal waters of Königshafen in summer. Therefore, the design of the plankton nets was optimized towards a most efficient collection of these specimens. Nevertheless, many other benthic taxa were also observed (Table 1), indicating that migrations are not confined to molluscs. However, since only a limited number of sites of mostly sandy sediment has been studied, the list is neither complete nor representative of the entire area. On the basis of observations of the weather conditions during and preceding the investigations, and of the light conditions, the most likely mode of water column entrance can be estimated. This requires two assumptions: (1) that a higher abundance in the water column during stormy weather than during a calm sea is indicative of passive erosion of the specimens from the sediment, and (2) that higher abundance in the dark than in daylight is indicative of active water-column entrance, provided weather conditions were similar. These two assumptions were derived from the more abundant meio- and macrobenthic species (see above and below). However, there are a few exceptions, e.g. a preference for daylight in mud snails Hydrobia ulvae.

Crustaceans enter the water column mainly by active swimming, and bivalves by byssus-drifting. Both active swimming and passive erosion occur in annelids. Only in the latter taxon are there some abundant species in the sediment that have not yet shown up in the water column, e.g. the polychaetes Heteromastus filiformis and Capitella capitata. Apart from these exceptions, Table 1 reads like a list of the abundant species at the sites studied. Thus, at least the potential for migration is rather general in the benthos of Königshafen.

\section{Rhythms of migratory activity}

Time series analyses of abundance in the plankton nets anchored at fixed sites revealed rhythms of migratory activity on various scales in all of the abundant postlarval molluscs in Königshafen. A diurnal rhythm was generally observed. Floating mud snails 
Table 1. Macrobenthic driftfauna in Königshafen. Author's own observations during summer 1990-1992 (mostly not previously published). Abundance (Ab.) categories: 0 single specimen; + several observations of single specimens; \# several observations, high abundance; ++ regular, low abundance; \#\# regular, high abundance. 'Mode of water column entry' is a best estimate according to the currently available data

\begin{tabular}{|c|c|c|c|c|}
\hline Species & $\begin{array}{l}\text { Size range } \\
\quad(\mathrm{mm})\end{array}$ & $\begin{array}{l}\text { Mode of water } \\
\text { column entry }\end{array}$ & $\mathrm{Ab}$. & Remarks \\
\hline \multicolumn{5}{|l|}{ POLYCHAETA } \\
\hline Phyllodoce mucosa & $10-40$ & $?$ & ++ & after gales \\
\hline Eteone longa & $10-20$ & ?active & $\#$ & during calm weather \\
\hline Nereis diversicolor & $5-20$ & active & $\#$ & during calm weather \\
\hline Nephtys hombergii & 40 & & 0 & \\
\hline Scoloplos armiger & $5-20$ & ?active & $\# \#$ & also algal rafting \\
\hline Lanice conchilega & 15 & & 0 & \\
\hline Pygospio elegans & $10-12$ & ?active & + & \\
\hline Polydora Ligni & & & 0 & \\
\hline Spio filicornis & & ?passive & + & \\
\hline Arenicola marina & $1-10$ & active & + & $\begin{array}{l}\text { juvenile migrations } \\
\text { in spring and autumn }\end{array}$ \\
\hline \multicolumn{5}{|l|}{ OLIGOCHAETA } \\
\hline Paranais litoralis & $8-15$ & ?active & \# & early summer only \\
\hline Tubificoides benedeni & & passive & + & during stormy weather \\
\hline \multicolumn{5}{|l|}{ GASTROPODA } \\
\hline Hydrobia ulvae & $0.5-5$ & floating & \#\# & \\
\hline Littorina saxatilis & 3 & & 0 & \\
\hline Littorina mariae & 3 & & 0 & \\
\hline \multicolumn{5}{|l|}{ BIVALVIA } \\
\hline Cerastoderma edule & $0.5-4$ & byssus-drift & $\# \#$ & \\
\hline Macoma balthica & $0.5-4$ & byssus-drift & \#\# & \\
\hline Ensis americanus & $1-18$ & byssus-drift & \#\# & ?also other modes \\
\hline Mytilus edulis & $1-2$ & byssus-drift & ++ & \\
\hline Venerupis pullastra & $1-2$ & byssus-drift & ++ & \\
\hline Mya arenaria & $1-2$ & byssus-drift & ++ & \\
\hline \multicolumn{5}{|l|}{ ISOPODA } \\
\hline Idotea baltica & & & + & ?algal rafting \\
\hline \multicolumn{5}{|l|}{ DECAPODA } \\
\hline Crangon crangon & & active & $\# \#$ & \\
\hline $\begin{array}{l}\text { Carcinus maenas (juveniles } \\
\text { and megalopae) }\end{array}$ & & active & $\# \#$ & \\
\hline $\begin{array}{l}\text { Eupagurus bernhardus } \\
\text { (megalopae) }\end{array}$ & & active & ++ & \\
\hline \multicolumn{5}{|l|}{ AMPHIPODA } \\
\hline Hyperia galba & & & ++ & \\
\hline Apherusa bispinosa & & & 0 & \\
\hline Atylus falcatus & & ?active & + & \\
\hline Atylus swammerdami & & active & ++ & \\
\hline Bathyporeia elegans & & active & + & \\
\hline Bathyporeia guilliamsoniana & & active & + & \\
\hline Bathyporeia pelagica & & active & + & \\
\hline Bathyporeia pilosa & & active & + & \\
\hline
\end{tabular}


Table 1 (Continued)

\begin{tabular}{|llll|}
\hline Species & $\begin{array}{c}\text { Size range } \\
(\mathrm{mm})\end{array}$ & $\begin{array}{c}\text { Mode of water } \\
\text { column entry }\end{array}$ & Ab. \\
\hline AMPHIPODA & & Remarks \\
Bathyporeia sarsi & active & + \\
Calliopius laeviusculus & & 0 & \\
Chaetogammarus marinus & & active & $\# \#$ \\
Corophium arenarium & active & + \\
Corophium volutator & & 0 \\
Dyopedos monacanthus & active & + \\
Gammarus salinus & active & $\# \#$ \\
Haustorius arenarius & ?active & + \\
Microprotopus longimanus & & acitve & $\#$ \\
Microprotopus maculatus & & 0 \\
Melita sp. & acitve & + \\
Pontocrates altamarinus & & \\
CUMACEA & & 0 \\
Bodotria arenosa & & + \\
Bodotria pulchella & & ++ \\
Bodotria scorpioides & ?active & + \\
Cumopsis goodsiri & active & + \\
Diastylis bradyi & ?active & + \\
Lamprops fasciata & ?active & + \\
Pseudocuma gilsoni & active & ++ \\
\hline
\end{tabular}

Hydrobia ulvae were more abundant during daylight than in the dark while the reverse was true for the abundant bivalves (cockles Cerastoderma edule, clams Macoma balthica, and razor clams Ensis americanus). Seasonal abundance in the water column is mainly a function of abundance in the sediment and individual size. Migratory activity in summer was confined to individuals smaller than $4 \mathrm{~mm}$. Seasonal abundance of this size class in the sediment limits the abundance of migrators in the water column (Armonies, 1992). In the bivalves there are additional rhythms linked with lunar phases. A semilunar periodicity, with peak abundances during spring tides, occurs in $C$. edule and $E$. americanus (Armonies, 1992). Whereas the above rhythms were independent of the intertidal position, $M$. balthica seems to be a special case. A 10-day rhythm of swimming activity was observed at a lower intertidal site in 1991 (Armonies, 1992) and at a mid intertidal site of Königshafen in summer 1992. However, the period of the rhythm tended to be longer at low tide level and shorter in the upper intertidal zone where the amplitude of the rhythms became smaller at the same time (Armonies, unpubl.). This may be a case of interference between a rather low amplitude semi-lunar rhythm and a diurnal rhythm. The diurnal rhythm largely determined the combined effect in the upper intertidal zone, whereas the semi-lunar periodicity increased in importance further down the tidal gradient.

The diurnal and semi-lunar rhythms of migratory activity may be distorted by the actual wind conditions. Wind exerts its influence in three ways, by changing the direction of the tidal currents in the shallow waters of the Wadden Sea, by changing the average current velocities, and by creating waves. A change of the direction of the tidal waters 
introduces additional variability into the time series of migratory activity since the water passing the plankton nets may have been loaded with drifters in areas with an ambient density of juveniles higher or lower than overall average. More pronounced is the effect of variations in current velocity. As was the case in the meiofaunal swimming behaviour in flume experiments (see above), increased current velocity in the field correlated negatively with abundance of molluscs in the water column (Armonies, 1992). Additional studies indicate also a changed species-specific vertical distribution pattern of drifters in the water column. As current velocity increases, the highest concentration of drifters in the water column is found closer to the sediment surface; this effect was strongest in mud snails and clams (Armonies, unpubl.). Possibly the current velocity at the water surface is too strong, then, to support byssus-drifting, while the currents closer to the sediment surface may still be favourable for drifting. Wave effects have hitherto not been studied because, due to the sheltered position of southern Königshafen, waves $>10 \mathrm{~cm}$ height are not frequent enough.

\section{Effects of migrations}

The change in distributional patterns caused by migrations of juveniles was studied in two species, mud snails Hydrobia ulvae and clams Macoma balthica. With regard to $M$. balthica, abundance and growth were studied at 6 sites along a transect between low tide level and high tide level (Armonies \& Hellwig-Armonies, 1992). While spatfall mainly occurred in the lower intertidal zone, subsequent migrations turned the pattern towards higher abundance in the upper intertidal within three months. Growth of the spat was faster in the upper intertidal throughout this period. Since the average size of drifting organisms in the water column did not significantly change seasonally (Armonies, 1992), the faster growth of spat in the upper intertidal results in a lower rate of emigration from these sites than from the lower intertidal with slow individual growth. It is an open question, however, whether this is the only mechanism causing the accumulation of juveniles in the upper intertidal during summer.

In southern Königshafen, between the dike and a seaward sandy bar, a semienclosed muddy bay of about $50000 \mathrm{~m}^{2}$ is present that is densely populated with mud snails throughout the year. Using a hydrographic model of the Königshafen area, Armonies \& Hartke (1994) modelled the directions of the tidal currents for various wind directions to predict the routes of dispersal of juvenile mud snails out of this semienclosed bay. Floating juveniles indeed accumulated in two patches on the predicted routes and temporarily attained abundances $>100000 \mathrm{~m}^{-2}$. However, virtually all the juveniles left these patches again in late summer and returned to the adult populations (Fig. 6). Thus, migrations did not result in a permanent enlargement of the occupied area but may have released juveniles from competition with adults and may have enabled genetic transfer between populations.

\section{Turnover of juvenile molluscs in the sediment}

Turnover of juvenile molluscs was studied in Königshafen sediments during summer, 1992 (Armonies, 1994; Armonies \& Hartke, 1994). Based on weekly intervals (because of the short-term rhythms of migratory activity, see above), turnover time of individuals varied strongly with season and lunar phases. Between June and August, the calculated 


\section{A. Patch foundation}

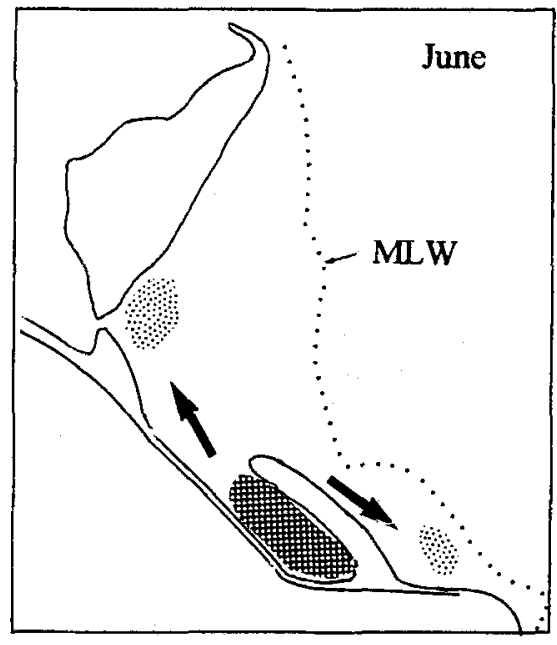

\section{B. Dynamic patch maintenance}

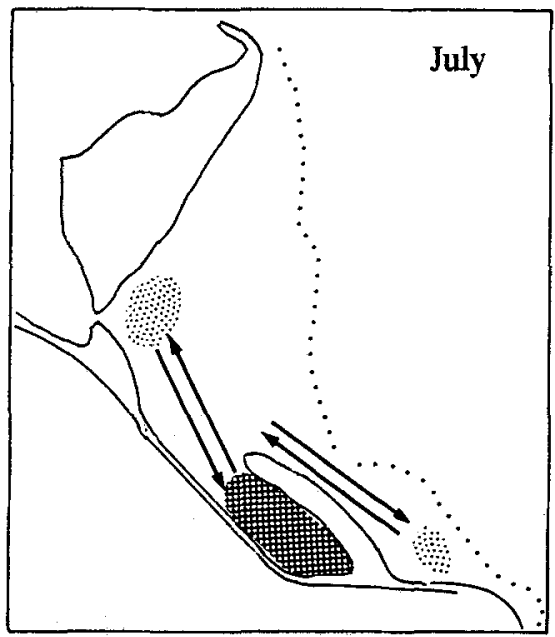

\section{Return to adult sites}

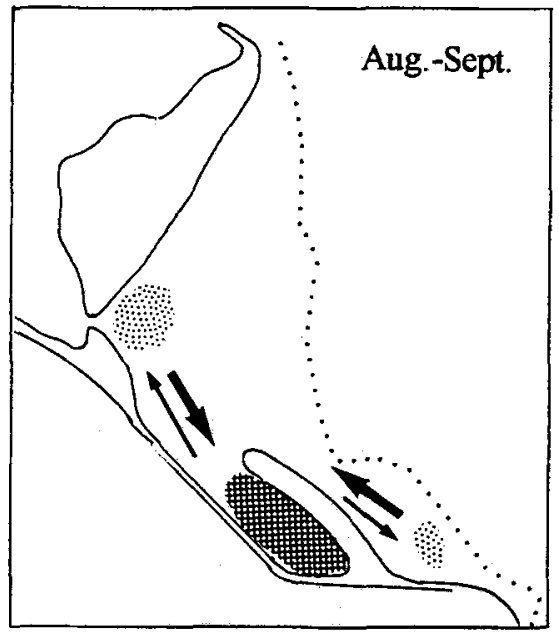

Fig. 6. Seasonal dynamics of juvenile mud snails Hydrobia ulvae. A: Patches of juveniles (light shading) were found in late June, 1992, caused by floating juveniles arriving from a densely populated adult site (dark shading). B: During July the juvenile patches were maintained by equal emigration and immigration, with individuals staying at the same site for about 2 days on average. C: In August, emigration from the juvenile patches dominated over immigration until they were completely depopulated again in September. Arrows indicate transport while afloat 
values ranged between 18 days and 3 min (Armonies \& Hartke, 1994; Armonies, 1994). On average, juveniles of Macoma balthica, Cerastoderma edule, and Hydrobia ulvae stayed no longer than 1 to 2 days at the same site in summer. Turnover time was mostly shorter in the lower than in the upper intertidal, which may be a consequence of the shorter period of submergence in the upper intertidal.

\section{DISCUSSION AND CONCLUSIONS}

How to deal with drifting benthos

The high mobility observed in some benthic taxa leads to methodological difficulties for almost any further study on these populations. Mobility is too high to be neglected but often too low to apply standard methods for sampling plankton. Thus, a combination of methods is needed. This does not mean, however, that a simple addition of benthic and planktonic methods would suffice. Apart from difficulties in applying traditional plankton gears in shallow waters, the inherent assumptions in the logic of methods will not be met. For example, in plankton ecology there is normally no need to assume that disappearance of nonlarval specimens from the water column had another reason than mortality. Therefore, new methods need to be developed reflecting both the potential for short-term and small-scale spatial variability. For the study of drift processes, high frequency sampling with replication in both the sediment and the water column worked quite well in the above studies on molluscs. But many questions remain unanswered, e.g. how many migrations do individuals perform per night, and what is the distance covered? Further work, particularly experimental, is needed to understand the various steps involved in drift processes.

The effects of migrations can be studied by repeated mapping of a sufficiently large area. The better other sources of spatial and temporal variability can be determined independently, the longer the intervals between mapping events may become. In this context, a hydrographic model of the studied area is a valuable tool since it can show the potential for transport between sites. Coupling such a model with an ecological submodel might result in predictions of the changes in distributional patterns as far as they are due to migrations with the currents. A very basic attempt in this field has been made by Armonies \& Hartke (1994).

\section{The purpose of drifting in the water column}

Migrations (defined as the act of moving from one spatial unit to another) achieved by drifting or swimming in the water column may be divided into active and inactive migrations. In inactive migrations, both the initiation and the mechanisms of migration are beyond the control of the animal concerned but are imposed on the animal by some environmental force that overrules the normal station-keeping mechanisms of the animal (Baker, 1978). The definition of migrations covers the suspension of benthic animals by either currents and wave action or by biotic disturbance, e.g. during the feeding activity of epibenthic species. The migrations directly resulting from such disturbance events are beyond the control of the organisms and thus have no purpose. Nevertheless, the effects 
of inactive migrations may be worthwhile studying in the case of large-scale spatial disturbances.

Active migrations, on the other hand, imply an active initiation of migrations by the animals. According to the time scales involved, the reasons for leaving the sediment may be arranged in a series ranging from sudden threats requiring an immediate response to adaptive migrations in the life history of a specimen.

In d i vid u a l e s c a p e - migrations are a reaction to an unexpected threat such as a predator attack that demands an immediate response. Typically, such migrations may have a time scale of seconds; they concern single individuals, and may be effective on a very small spatial scale (Fig. 7).

Individual escape from the sediment as a predator-avoidance reaction has been

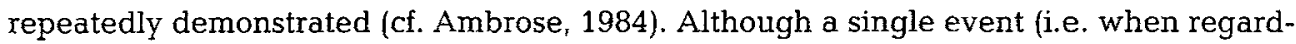
ing one single specimen) is hard to predict, the combined effect of all predators on a local population of prey specimens may result in a negative correlation between local predator and prey abundances, hence affect small-scale spatial distribution. However, if the prey is able to perceive the presence of the predator, it is certainly advantageous to leave this place before an attack occurs. As an adaptive strategy, the prey should avoid areas with high predator abundance. On the other hand, the predator should attack its prey while it has no chance to escape, e.g. during low tide in the present context. Both strategies have been shown to occur among predatory nemertines and their prey on the tidal flats of Königshafen (Thiel \& Reise, 1993).

Group evasion - migrations are reactions to factors accumulating over some time and requiring a response in the near future (in the present context this may commonly be the next nocturnal high tide). Examples are environmental deterioration or resource depletion, either physical (e.g. oxygen, temperature, salinity) or biotic (e.g. overcrowding, interspecific competition). These migrations concern local groups of specimens on a time scale of hours to days and require a larger spatial scale in order to be effective.

In group evasion from a physically deteriorated environment or as a consequence of resource depletion, specimens get a chance to find more benign conditions. As an adaptive strategy, specimens need to find a balance between the risks of migration in the water column, the risks of staying in the sediment, and the chance to find a better habitat. An evaluation of the latter two factors will depend on the individual demands with respect to habitat quality. The result will vary with the species. But some general suggestions of methods to reduce the risks during migrations in the water column may be given. These include avoidance of visually hunting predators by nocturnal migration and avoidance of stronger currents which could carry the migrants beyond the suitable range of habitats. As was demonstrated above, most specimens indeed favour nighttime to daytime and weak currents to strong currents for their migrations in Königshafen. An increasing number of studies show that group evasion really does occur in various taxa and habitats. Examples are plathelminth evasion from intertidal sediment covered by algal mats that cause oxygen depletion (Reise, 1983), density-dependent emigration in subtidal amphipods (Ambrose, 1986), and emigration of Corophium volutator in experiments with increased abundance of the sediment disturber and predator Nereis diversicolor (Rönn et al., 1988).

Habitat changing of populations - prospective migrations not neces- 

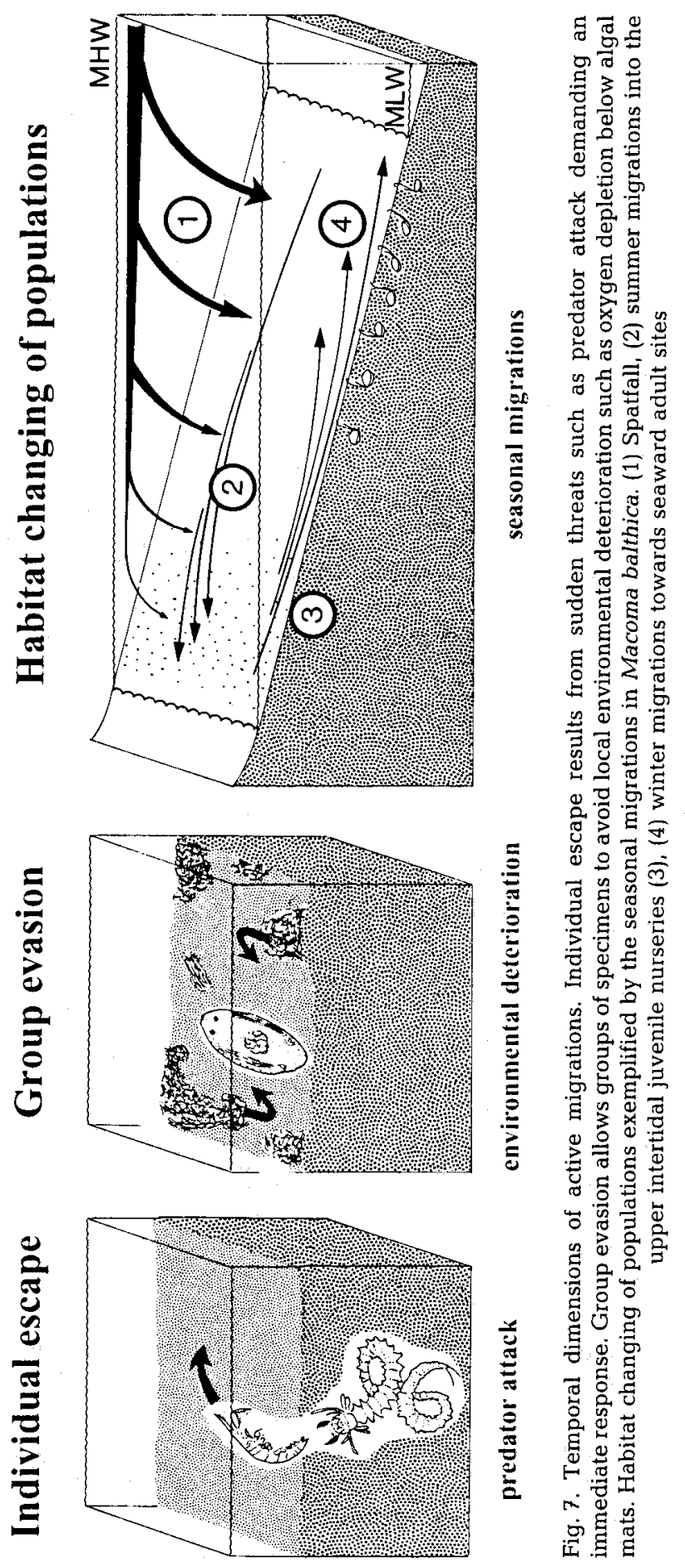
sarily indicated by actual constraints, concerning populations or age groups (evolutionary adaptations, Fig. 7). A typical example may be winter migrations of Macoma 0-group to another habitat of the Wadden Sea (Beukema \& de Vlas, 1989). The time and spatial scales may be much smaller in meiobenthic than in macrobenthic species.

Habitat changing of populations occurs in temporal scales of hours to seasons, and in spatial scales of $\mathrm{cm}$ to $\mathrm{km}$. Since these migrations are not necessarily driven by exogeneous factors (although such factors may function as a zeitgeber), they have the highest adaptive value in the series. Examples range from the nocturnal emergence of benthic harpacticoid copepods for food uptake in the water column (Decho, 1986) to seasonal changes of the occupied position in the tidal gradient in the polychaete Arenicola marina (Beukema \& de Vlas, 1979; Reise, 1985) or the bivalve Macoma balthica (Beukema \& de Vlas, 1989; Armonies \& Hellwig-Armonies, 1992; Beukema, 1993). Since in this type of migration entire populations or age classes are concerned, its quantitative effects are presumably the strongest. The specific advantages of change of habitat are also the most diverse among the various types of migrations. This is expected because all factors causing escape and evasion migrations may also lead to an adaptive change of habitat if they are sufficiently frequent and regular in time. Additional advantages of habitat changing are only valid during certain phases in the life history. Examples are migrations for moulting, mating, or breeding (Bell et al., 1988; Walters, 1991). In addition, migrations may be indicated if juveniles and adults differ in their ranges of environmental factors preferred or tolerated.

However, although migrations may be an advantageous reaction to many risks, they do not seem to be equally important in all taxa. In nematodes, for example, active migrations are rather uncommon (Heip et al., 1985). Nematodes often have high rates of reproduction, many generations per year, and a wide tolerance towards environmental factors (Heip et al., 1985). These features may be regarded as a (non-exclusive) alternative to migrations ensuring species survival while the habitat deteriorates in various temporal scales.

\section{Consequences for benthic field research}

In meiofauna, migrations were found to be quantitatively significant in about half of the species studied. In molluscs, drifting turned out to be quantitatively important in all species occurring in Königshafen except in Littorina and Retusa obtusa (which does not mean, however, that the latter species do not migrate, but only that they did not show up in the water column in summer). We observed most of the polychaete species occurring at the studied sites also drifting or swimming in the water column. Therefore, there is no reason to assume, a priori, that migrations were less important in polychaetes. Finally, swimming in amphipods, cumaceans, and isopods is already a well-known phenomenon (Sainte-Marie \& Brunel, 1985; Maquart-Moulin, 1991; Warman et al., 1991). Since migrations may change local abundances and size distribution, they are likely to interfere with all kinds of field studies on populations (e.g. growth, production, survival) unless an experimental approach is followed that excludes migration.

Unfortunately, the potential of species for migrations is not easily estimated because it may vary over seasons and during the specific life-history. Rhythms of migratory activity, like the peaks of abundance of drifting cockles and razor clams during spring tides, further add to the complexity. To avoid pitfalls, individual biologists may escape 
from the incalculable effects of migrations by turning towards controlled laboratory experiments, with all the known constraints. But since uneasiness concerning the potential for migrations has accumulated over the past years, groups of field ecologists will certainly need to avoid the pitfalls by developing new methods and concepts for field research. Finally, at least local populations of ecologists will have to change their views about habitat-dependence of species, studying benthic populations in the sediment, in the water column, or both, depending on what is more suitable during the next step of their analysis. Generally, in the study of benthic communities and populations a repeated mapping approach seems to be the appropriate alternative to 'station sampling'. In a discussion of the mosaic-cycle concept of marine ecosystems, Reise (1991) came to the same conclusion; albeit here the argument is a 'holobenthic' one.

Acknowledgements. This study was supported by a grant from the Federal Ministry for Research and Technology. This is publication no. 123 of the project "Ecosystem Research Wadden Sea".

\section{LITERATURE CITED}

Ambrose, W. G., 1984. Increased emigration of the amphipod Rheopoxynius abronius (Barnard) and the polychaete Nephtys caeca (Fabricius) in the presence of invertebrate predators. - J. exp. mar. Biol. Ecol. 80, 67-75.

Ambrose, W. G., 1986. Experimental analysis of density dependent emigration of the amphipod Rheopoxynius abronius. - Mar. Behav. Physiol. 12, 209-216.

Armonies, W., 1986. Plathelminth abundance in North Sea salt marshes: environmental instability causes high diversity. - Helgoländer Meeresunters. 40, 229-240.

Armonies, W., 1988a. Active emergence of meiofauna from intertidal sediment. - Mar. Ecol. Prog. Ser. $43,151-159$.

Armonies, W., 1988b. Hydrodynamic factors affecting behaviour of intertidal meiobenthos. Ophelia 28, 183-193.

Armonies, W., 1988c. Physical factors influencing active emergence of meiofauna from boreal intertidal sediment. - Mar. Ecol. Prog. Ser. 49, 277-286.

Armonies, W., 1988d. Common pattern of plathelminth abundance in North Sea salt marshes and in the Baltic Sea. - Arch. Hydrobiol. 111, 625-636.

Armonies, W., 1989a. Occurrence of meiofauna in Phaeocystis seafoam. - Mar. Ecol. Prog. Ser. 53, 305-309.

Armonies, W., 1989b. Semiplanktonic Plathelminthes in the Wadden Sea. - Mar. Biol. 101, 521-527.

Armonies, W., 1989c. Meiofaunal emergence from intertidal sediment measured in the field: significant contribution to nocturnal planktonic biomass in shallow waters. - Helgoländer Meeresunters. 43, 29-43.

Armonies, W., 1990. Short-term changes of meiofaunal abundance in intertidal sediments. Helgoländer Meeresunters. 44, 375-386.

Armonies, W., 1992. Migratory rhythms of drifting juvenile molluscs in tidal waters of the Wadden Sea. - Mar. Ecol. Prog. Ser. 83, 197-206.

Armonies, W., 1994. Turnover of postlarval bivalves in sediments of tidal flats in Königshafen (German Wadden Sea). - Helgoländer Meeresunters. 48, 291-297.

Armonies, W. \& Hartke, D., 1994. Floating of mud snails (Hydrobia ulvae) in tidal waters of the Wadden Sea, and its implications in distribution patterns. - Helgoländer Meeresunters. 49. (In press).

Armonies, W. \& Hellwig-Armonies, M., 1992. Passive settlement of Macoma balthica spat on tidal flats of the Wadden Sea and subsequent migrations of juveniles. - Neth. J. Sea Res. 29, 371-378.

Baker, R. R., 1978. The evolutionary ecology of animal migration. Hodder \& Stoughton, London, $1012 \mathrm{pp}$.

Bell, S. S., Hicks, G. R. F. \& Walters, K., 1988. Active swimming in meiobenthic copepods of seagrass 
beds: geographic comparisons of abundance and reproductive characteristics. - Mar. Biol. 98, 351-358.

Beukema, J. J., 1993. Successive changes in distribution patterns as an adaptive strategy in the bivalve Macoma balthica (L.) in the Wadden Sea. - Helgoländer Meeresunters. 47, $287-304$.

Beukema, J. J. \& Vlas, J. de, 1979. Population parameters of the lugworm, Arenicola marina, living on tidal flats in the Dutch Wadden Sea. - Neth. J. Sea Res. 13, 331-353.

Beukema, J. J. \& Vlas, J. de., 1989. Tidal-current transport of thread-drifting postlarval juveniles of the bivalve Macoma balthica from the Wadden Sea to the North Sea. - Mar. Ecol. Prog. Ser. 52, 193-200.

Decho, A. W., 1986. Water-cover influences on diatom ingestion rates by meiobenthic copepods. Mar. Ecol. Prog. Ser. 33, 139-146.

Essink, K., Kleef, H. K. \& Visser, W., 1989. On the pelagic occurrence and dispersal of the benthic amphipod Corophium volutator. - J. mar, biol. Ass. U.K. 69, 11-15.

Heip, C., Vincx, M. \& Vranken, G., 1985. The ecology of marine nematodes. - Oceanogr. mar. Biol. a. Rev. 23, 399-489.

Macquart-Moulin, C., 1991. La phase pélagique nocturne des Cumacés. - J. Plankton Res. 13, 313-337.

Newell, R., 1962. Behavioural aspects of the ecology of Peringia (= Hydrobia) ulvae (Pennant) (Gastropoda, Prosobranchia). - Proc. zool. Soc. Lond. 138, 49-75.

Reise, K., 1983. Sewage, green algal mats anchored by lugworms, and the effects on Turbellaria and small Polychaeta. - Helgoländer Meeresunters. 36, 151-162.

Reise, K, 1985. Tidal flat ecology. Springer, Berlin, $191 \mathrm{pp}$.

Reise, K., 1988. Plathelminth diversity in littoral sediments around the island of Sylt in the North Sea. - Prog. Zool. 36, 469-480.

Reise, K., 1991. Mosaic cycles in the marine benthos. In: The mosaic-cycle concept of ecosystems. Ed. by H. Remmert. Springer, Berlin, 61-82.

Rönn, C., Bonsdorff, E. \& Nelson, W. G., 1988. Predation as a mechanism of interference within infauna in shallow water soft bottoms; examples with an infauna predator, Nereis diversicolor O. F. Müller. - J. exp. mar. Biol. Ecol. 116, 143-157.

Sainte-Marie, B. \& Brunel, P., 1985. Suprabenthic gradients of swimming activity by cold-water gammaridean amphipod Crustacea over a muddy shelf in the Gulf of Saint Lawrence. - Mar. Ecol. Prog. Ser.23, 57-69.

Sigurdsson, J. B., Titman, C. W. \& Davies, P. A., 1976. The dispersal of young post-larval bivalve molluscs by byssus threads. - Nature, Lond. 262, 386-387.

Thiel, M. \& Reise, K., 1993. Interaction of nemertines and their prey on tidal flats. - Neth. J. Sea Res. $31,163-172$.

Walters, K., 1991. Influence of abundance, behavior, species composition, and ontogenetic stage on active emergence of meiobenthic copepods in subtropical habitats. - Mar. Biol. 108, 207-215.

Warman, C. G., O'Hare, T. J. \& Naylor, E., 1991. Vertical swimming in wave-induced currents as a control mechanism of intertidal migration by a sand-beach isopod. - Mar. Biol. 111, 49-54. 